\title{
Model Pelayanan Kesehatan ditinjau dari Aspek Kualitas, Manajemen dan Sumber Daya Kesehatan di RSUP dr. Kariadi Semarang 2018
}

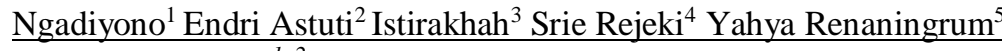 \\ 1, 2 Poltekkes Kemenkes Semarang \\ ${ }^{3,4,5}$ Hospital midwives Dr. Kariadi Semarang \\ Corresponding author: Ngadiyono \\ Email: ngdiyono@gmail.com
}

Received: March 28 ${ }^{\text {th }}, 2019$; Revised: April 19 ${ }^{\text {th }}, 2019$; Accepted: April 26 $6^{\text {th }}, 2019$

\begin{abstract}
Current service providers must maintain quality, if customers do not want to be left behind. This includes Health Services from the Aspects of Perception of Quality, Management and Human Resources (HR) Health implemented at Dr. Hospital. Kariadi Semarang.The study was carried out using an interpretive qualitative naturalistic type / approach. With concurrent transpormative strategies, namely starategi uses a theoretical perspective to form a framework for research topics, data collection techniques and expected results from research.The results showed that the perceptual aspects of service quality were carried out in accordance with the SPO, local values, administration and regula- tion that were tailored to the patient's needs, responsive by being asked 3T and 1D (ask: conditions, complaints and facilities and prayers), and oriented to International Patient Safety Goal (IPSG) Case management (Interprofessional collaboration), limited to multidisciplinary models with authority authority in the form of Doctor in Charge of Services (DPJP) and Nurse Responsible Services (PPJP) and assisted by Associate Nurses (PA) provided interdisciplinary means and integrated notes as a model of interaction between professionals who are bound in teams. Next for the management of Human Resource management, (education, service coordination, compliance, transition management, and utilization manage-ment), it has been implemented as needed and is a comfortable place for a career.The three aspects of management's assessment, have been implemented well, only in case management using a multidisciplinary model, and have not used an international collaborative model, with limited interaction between professions in managing patients that still need to be improved.
\end{abstract}

Keywords: model; service; health; Dr. Hospital Kariadi

\section{Pendahuluan}

Beberapa hasil penelitian yang menunjukan hasil interaksi tenaga ke-sehatan dan pasien sebagai pengguna jasa pelayanan kesehatan, misalnya penelitian Ketut Gunawan dan Sun dring Pantja Djati, 2011, menunjukan bahwa demensi mutu kehandalan (reliability) sebagai dimensi yang mempunyai pengaruh dominan terhadap loyalitas pasien dapat dijadikan keunggulan.

Sedangkan Improtul Kasanah dan Otarina, 2010, hasil penelitiannya menyimpulkan bahwa Kepuasan konsumen yang dipengaruhi oleh wujud fisik, kehandalan, daya tanggap, jaminan dan empati sebesar 71,6 persen, sehingga 28, 4 persen masih dipenga-ruhi oleh variabel lain, diharap-kan dalam penelitian selanjutnya dapat menambahkan variabel variabel lain yang dapat mempengaruhi kepuasan konsumen R.S.St. Elisabeth, misal seperti mudah dijangkaunya lokasi, biaya yang dikeluarkan dan lain-lain, atau pada obyek yang berbeda.

Dalam kontek penelitian ini yang menjadi pertanyaan umum adalah bagaimanakah model pelayanan yang dapat dilaksanakan. Dalam konsep pelayanan, tidak akan lepas dari pemahaman tentang hubungan atau interaksi tenaga kesehatan dan pasien. Para ahli antara lain Hays and Larson, 1996, mengidentifikasi sejumlah teknik yang dikenal dengan komunikasi terapetik dan dikatakan bahwa yang memiliki kemampuan komunikasi terapetik akan mudah menjalin hubungan saling percaya. Namun diingatkan oleh Burmard, 1990, persepsi sebuah kualitas bagi seorang bersifat individual yang didasarkan pada pengalaman individu dan ini merupakan keunikan sebagai 
individu manusia itu sendiri.

Itu artinya konsep-konsep tentang hubungan tenaga kesehatan dan pasien yang telah disusun harus tetap dipadukan dengan harapan pasien secara individual dan dilaksanakan menggunakan model asuhan. Lalu bagaimana model model asuhan yang dapat dilaksanakan?. Benarkah keyakinan tentang keprofesian dan kemampuannya menggunakan model pelayanan dalam perkembangan terakhir ini telah sesuai dengan harapan sehingga dapat memuaskan pasien.

Secara umum penelitian ini ingin mencari jawaban gambaran model pelayanan kesehatan akan memberikan dampak peningkatan kualitas pelayanan kesehatan kepada pasien. Dan khusus dari pertanyaan masalah tersebut dapat sampaikan pertanyaan masalah yang lebih spesifik yaitu:

Gambaran Model Pelayanan Ke-sehatan dari Aspek Persepsi, Manajemen Pelayanan Kesehatan dan SDM Kesehatan, kemudian pertanyaannya adalah pertama, bagaimana implementasi pelayanan kesehatan pada pasien dari aspek persepsi, kedua, bagaimana gambaran model pelayanan kesehatan pada pasien dari aspek Manajemen pelayanan kesehatan dan ketiga, bagaimana pelayanan dari aspek Manajemen Sumber Daya Manusia Kesehatannya.

Gambaran umum tentang kebu-tuhan dan keinginan pasien terhadap pelayanan kesehatan sangat diperlukan agar tercapai kesatuan arah / tujuan, sehingga dalam impelementasinya akan terjadi kerjasama yang baik antara pasien dan tenaga kesehatan. Secara khusus yang ingin diketahui dan menjadi tujuan dalam penelitian ini adalah, pertama mengetahui kualitas pelayanan atau asuhan kesehatan pada pasien dari aspek persepsi, kedua mengetahui model asuhan atau pelayanan kesehatan pasien dari aspek Manajemen pelayanan kesehatan. Dan ketiga mengetahui arah pengelolaan sumber daya dari aspek Manajemen Sumber Daya Manusia Kesehatan.

\section{Metode Penelitian}

Metode penelitian kualitatif digunakan untuk penelitian ini, dengan mengangkat masalah yang mengacu pada perspektif tenaga kesehatan dan atau pemberi pelayanan kepada pasien, atau dalam penjelasan Dorothy Young Brockopp, 1995, jika peneliti berminat melalukan penelitian dari perpektif kualitas maka jenis kualitatif yang lebih tepat.

Pendekatan yang digunakan adalah kualitatif naturalistik-interpretif, yaitu sebuah pendekatan dilaksanakan oleh karena sudah jelas kerangka pemikirannya, filsafat yang melandasinya, ataupun operasionalisasi metodologinya sebagai bangunan paradigma keilmuan, bukan sekedar reaktif atau menggugat paradigma keilmuan kuantitatif (Muhadjir, 2007:136-140). Dan strategi yang peneliti gunakan ini adalah strategi transpormatif concu-rrent, yaitu salah satu dari tiga Concurrent mixed methods, dua yang lain, strategi triangulasi konkuren dan strategi embedded konkuren. Titin Ariska Sinaryatin, (2013) yaitu strategi menggunakan perspektif teori untuk membentuk kerangka kerja untuk topik penelitian, teknik pengumpulan data dan hasil yang diharapkan dari penelitian.

Desain Concurrent mixed methods digunakan oleh karena adanya konsep/teori pelayanan kebidanan dan kesehatan serta implementasinya menggunakan teori manajemen pelayanan yang telah dikembangkan oleh masing masing bidang pelayanan, sehhingga penggabungan antara teori dan keinganan pasien adalah sesuatu yang penting untuk diperhatikan oleh setiap pemberi pelayanan.

Populasi penelitian meliputi 8 instalasi yang ada di RSUP Dr. Kariadi Semarang dan sampelnya adalah purposif atau sampel bertujuan, Maksud sampling adalah menjaring sebanyak mungkin informasi dari berbagai sumber yang akan digunakan sebagai dasar dari rancangan atau menyusun teori dan satuan kajiannya bersifat perorangan.

\section{Hasil dan Pembahasan}

Rumah Sakit Umum Pusat (RSUP) Dr. Kariadi Semarang rumah sakit terbesar di Jawa Tengah yang menyelenggarakan pelayanan kesehatan dan rujukan paripurna, bermutu, menjamin keselamatan pasien dan menjangkau seluruh masyarakat. (Profil RSUP Dr. Kariadi Semarang, 2016).

Untuk mewujudkan pelayanan yang bermutu tinggi, menjamin keselamatan pasien diperlukan adanya manajemen pelayanan yang berkualitas, hal ini sesuai dengan misi pertama rumah sakit.

Pada tahap ini kegiatannya adalah melakukan pengolahan data dengan cara pengelompokan data yang berasal dari kartu data sebagai data dasar yang bersumber dari hasil Fokus Group Diskusi (FGD), pengamatan dan atau observasi peneliti sebagai instrumen penelitian.

Data yang terkumpul dalam catatan lapangan disusun dalam kartu data, kemudian 
disusun dalam satuan. Satuan-satuan data ini merupakan bagian terkecil data yang terdiri dari beberapa kartu data dan atau dapat berdiri sendiri dan terlepas dari bagian yang lain.

Langkah selanjutnya adalah kategorisasi, yaitu satu pengelompokan data dari seperangkat tumpukan yang disusun atas dasar pikiran, intuisi, pendapat atau karakter tertentu.

\section{Penafsiran Data}

Setelah dilakukan pengkategorian data, dari rangkaian penelaahan data menjadi kata kunci. Kata kunci dari tiga aspek penelitian, masing masing diuraikan dalam dimensi, yaitu:

\section{Aspek Pelayanan Kesehatan dari Persepsi.}

a) Rumusan kualitas Jasa, sebagai kata kunci didapatkan:

1) Tindakan sesuai SPO dan

2) Asuhan sesuai nilai lokal (kepercayaan, interditas, peduli)

3) Pelayanan administrasi sesuai aturan.

4) Layanan berorientasi pasien, dengan indikator IPSG (Internasional Patient Safety Goal).

5) Pelayanan yang direncanakan.

6) Regulasi yang memberikan penghargaan.

b) Aspek fasilitas Interior Eksterior, didapatkan kata kunci:

1) Interior bagus.

2) Belum seragam.

3) Tingkat kelas sama tapi fasilitas beda.

4) Eksterior bagus dan megah

5) Belum ada ATM bersama

6) Parkir kurang luas

7) Kebersihan sangat terjaga.

c) Aspek reliabilitas Pelayanan yang akurat memenuhi janji, kata kunci:

1) Pelayanan tepat waktu.

2) Ada keluhan, kecepatan dan ketepatan pelayanan.

3) Janji janji kadang kurang tepat.

4) Rahasia pasien terjaga.

5) Setiap regulasi dilaksanakan dengan baik.

d) Aspek Interaksi Personal, kepercayaan kepada pasien dan Sikap tenaga kesehatan, kata kunci yang didapatkan:

1) Petugas dipercaya pasien.

2) Responsif/peka.

3) Sopan.

4) Tapi masih ada yang ketus, tidak banyak.

5) Cukup peka.
6) Harus ditanyakan 3T dan 1D.

7) Tanyakan kondisi, keluhan dan sarana prasarana serta doakan.

8) Interaksi baik

9) Satuan pengamanan siaga.

e) Aspek Pemecahan masalah kepekaan tenaga kesehatan, kata kuncinya:

1) Peka tapi ada juga yang kurang.

2) Perawat bisa merasakan apa yang dirasakan pasien (empati)

3) responsive

f) Aspek Kebijakan, kata kunci yang didapatkan:

1) Memenuhi kebuhan pasien.

2) jam buka, sesuai jadual.

3) fasilitas umum, nyaman dan teduh serta dekat dengan.

4) dibangun tempat parkir

5) jam berkunjung terlalu ketat.

6) Kendaraan umum untuk pengunjung.

Aspek Model Pelayanan dari Aspek Manajemen Pelayanan Kesehatan.

a) Model Segitiga Pelayanan.

1) Strategi Pelayanan.

Program pelayanan kepuasan pelanggan Standart pertanyaannya, kata kunci yang didapatkan:

- Orientasi pelayanan pada pasien.

- Quisener pasien rawat inap.

- Usaha pemenuhan kebutuhan pasien.

- Bangun khusus gedung parkir.

- Jaga kebersihan.

- Rencana ATM senter.

- Ada "respon Time" (indikator mutu.

- Standart performan pegawai.

- Teknologi modern "pendaftaran on line"

2) Sistem pelayanan yang diinginkan tempat pelayanan yang nyaman, cepat, tepat dan ramah, penggunaan teknologi yang canggih, dan lain sebagainya, kata kuncinya:

- Buku panduan pelayanan pasien.

- Panduan mudah diakses.

- Pelayanan diusahakan tepat waktu.

- Dijelaskan alasan penundaan pelayanan.

- Tidak tepat waktu kasuistis.

3) SDM yang sesuai dengan kebutuhan, kata kuncinya:

- Kebutuhan pasien diutamakan.

- Implentasi sesuai pengkajian.

- Tes masuk non PNS sangat ketat. 
- Sangat berkompetan.

- Memiliki sup spesialistik di semua bagian.

- Ahli dibidangnya.

- Menjadi rujukan nasional.

\section{b) Model American Case Management} Association (AMCA). atau Pengelolaan.

1) Akuntabilitas. Kebutuhan pasien sebagai praktik kolaboratif; menghargai martabat pasien; menghargai budaya; berkerjasama dengan pasien; hubungan saling percaya; mengelola dilema etik; perilaku jujur; kompetensi profesi sesuai dengan lingkupnya, kata kunci yang didapatkan:

- Model praktik kolaboratif.

- Cakupannya pasien, perawat, pekerja sosial, dokter dan nakes lain.

- Setuju case manajer.

- Ada lembar interdisiplin.

- Ada lembar catatan terinte-grasi.

- Catatan ditulis dalam satu rekam medis.

- Waktu untuk duduk bersama sulit.

- Diskusi antar prfesi belum berjalan dengan baik.

- Waktu untuk DPJP sangat sempit.

2) Profesionalisme. Mengkomunikasikan peran profesi; mengenali keterbatasan ketrampilan dan pengetahuan; melibatkan semua profesi; kata kunci yang didapatkan:

- Semua masalah pasien dilayaani oleh masing masing profesi.

- Pelayanan komprehensif.

- Pelaksana asuhan adalah Profesional Pemberi Asuhan (PPA)

- Menanyakan 3T 1 D, kondisi, keluhan dan sarana prasarana serta doakan.

- Interaksi sukup baik.

3) Kolaborasi Komunikasi dan koordinasi antar Profesi, kata kunci yang didapatkan:

- Pasien datang dilakukan penapisan.

- Asesmen awal oleh medis dan perawat.

- Dikinformasikan tindak lanjut pelayanan.

- Pelayanan diberikan komprehensive.

- Pelayanan dengan PPA.

4) Pengelolaan Sumber daya dan advokasi.

kepemimpinan dalam praktik kolaborasi; motivasi diri; berbagai akontabilitas; memperlihat-kan performence; bekerja dalam tim sesuai peran dan fungsi, kata kuncinya:

- Pasien dirawat sesuai masalahnya.

- Perlunya PPA bagi apsien.
- Syarat pemulangan pasien dalam konsi stabil.

- Pelayanan yang dibutuhkan dapat diakses.

- Melibatkan langsung dalam setiap tindakan.

- Hak menyetujui / menolak tindakan.

- Ada informed counsent atau informed choice.

\section{c) Aspek Model Pengembangan Sumber Daya:}

\section{Model Aspek SDM}

1) Arah Pengembangan SDM Pengembangan Karir, kata kunci yang didapatkan:

- Pengembangan karir di RSUP cukup menjajikan.

- Ada reward disetiap jenjang karir.

- Bentuk reward tunjangan kinerja.

2) Pendidikan Berkelanjutan

- Model seleksi dalam pendidikan berkelanjutan.

- Dua periode pendaftaran dalam satu tahun.

3) In Service Training

- Dilakukan oleh diklat.

- Dilakukan analisis kebutuhan pegawai.

\section{Model SDM dengan $7 \mathrm{P}$}

Perencanaan, Penerimaan, Pengembangan, Pembudayaan, Pendayagunaan, Pemeliharaan, Pensiun, kata kuncinya:

a) Pengembangan pegawai melaui tugas belajar dan ijin belajar serta pelatihan.

b) Ada relevansi dengan tugas dan kewenangannya.

c) Dilakukan mapping tenaga dan penempatan sesuai kompetensi.

d) Dilakukan uji kompetensi oleh Asessor.

e) Proses kredensial oleh mitra bestari.

f) Pemeliharaan kinerja dengan rekreasi.

g) Disediakan fasilitas rekreasi.

h) Akomodasi gratis dan uang saku.

i) Tunjangan berbasis kinerja.

j) Berkinerja baik diperbolehkan ambil masa BT.

k) Ada pesangon bagi Non PNS.

Hasil analisis kualitatif dilaksanakan dengan membandingkan secara kualitatif antara hasil pengakategorian data dengan teori yang telah disusun sebelumnya. Kategorisasi data disusun dengan mengambil inti dari kumpulan data dari tipologi satuan yang telah disusun sebelumnya untuk dijadikan kata kunci darisetiap kategori, 
sehingga dapat digunakan bahan untuk menyusun hasil penelitian ini.

Pembahasan hasil penelitian ini akan peneliti sampaikan secara urut mulai dari Aspek persepsi kemudian dilanjutkan dengan Model Manajemen Pelayanan dan terakhir pada Manajemen Sumber Daya Manusia.

\section{Aspek persepsi.}

Dalam masalah aspek persepsi, merupakan pandangan yang diberikan oleh orang lain terhadap kualitas kegiatan atau tindakan yang dilaksanakan untuk menunjuk pada kondisi yang sangat baik menurut ukuran tertentu yang disepakati. Demikian halnya Pelayanan Kesehatan dari Persepsi Kualitas Jasa yang dilaksanakan di RSUP Dr. Kariadi Semarang, menggunakan standar ukuran kualitas tindakan dengan SPO, menggunakan prinsip nilai yang diyakini baik, yaitu nilai lokal seperti kepercayaan, integritas dan peduli.

Ukuran lain yang digunakan adalah menggunakan indikator IPSG (International Patient Safety Goal) ada 6 sasaran keselamatan pasien. IPSG ini dikelurakan oleh JCI (Joint Commi-ssion International) sebuah lembaga yang memberi perhatian terhadap kualitas dan keselamatan kesehatan.

IPSG memiliki 6 goal keselamatan pasien, yaitu:

- Ketepatan identitas pasien.

- Komunikasi efektif.

- Keamanan obat.

- Kepastian tepat lokasi, tepat prosedur dan tepat pasien operasi.

- Pengurangan resiko infeksi.

- Pengurangan resiko jatuh.

Dan RSUP dr. Kariadi telah menggunakan standar kualitas pelayanan yang dikeluarkan oleh JCI ini disamping juga menggunakan standart Standar prosedur, menepati dan mematuhi regulasi yang ada dan digunakan di rumah sakit.

"Menurut penglihatan saya para perawat sudah memberikan pelayanan yang terbaik menurut standar prosedur yang dibuat"

"sudah jauh lebih baik bila dibandingkan dengan jaman dahulu, sekarang semuanya harus diren-canakan apa yang dikerjakan, atau ada istilah apa yang dikerjakan harus ditulis dan apa yang ditulis harus dikerjakan"

"mengerjakan tugas dan kewajibannya sangat bagus, apa lagi sekarang sudah ada uangnya, semua yang dikerjakan adsa nilainya"

Dengan demikian jika dipersepsikan sebagai pelayanan yang berkualitas sudah selayaknya dianugerahkan pada pelayanan kesehatan di rumah sakit.

Aspek fasilitas interior dan eksterior, berdasarkan pernya-taan responden menyatakan sudah cukup bagus, tetapi ada beberapa yang diusulkan, misalnya resto yang buka 24 jam, ATM center, perluasan are parkir, petunjuk atau denah ruangan khususnya di UGD yang kurang jelas.

Ada persebagai usulan misal-nya perluasan are parkir, penambahan area, misalnya ruang laktasi, tempat untuk charger untuk para pengunjung dan atau kurang bagus dalam bagian tertentu, sebagaimana pernyataan dalam tipologi satu-an sebagai berikut:

"Fasilitas di RS cukup lengkap mulai dari warung makan, resto cepat saji dan minimarket. Hanya saja tidak ada yang buka 24 jam. Sehingga apabila memerlukan membeli kebutuhan di malam hari agak kesulitan."

"Belum adanya ATM Center yang lengkap dari beberapa bank"

Pernyataan responden yang dikaitkan dengan reliabilitas dalam pelayanan yang memenuhi dan ketepatan janji dapat peneliti sampaikan beberapa contoh pernyataannya:

"dilihat dari keluhan pasien terhadap pelayanan yang diberikan dari tenaga kesehatan menurut saya masih ada, misalnya kecepatan pelayanan ketika dimintai tolong tentang tidak segera dilaksanakan--- apa istilahnya, kurang nglegake --- kalau orang Jawa mengatakan"

"Pegawai dalam menumbuhkan kepercayaan pasien dengan memberikan informasi yang sebenarbenarnya tentang penyakitnya dan dapat diajak berdiskusi."

Contoh pernyataan responden tentang kebutuhan pasien terpenuhi dan atau tidak terpenuhinya permintaan, tetapi dapat "nglegake" atau mungkin disamakan dengan memuaskan pasien ternyata terletak pada pemberian penjelasan atau informasi yang baik dan dapat dimengerti. Atau dalam istilah Komunikasi antar profesi yang baik, dapat mengkoordinasikan dan mengkomunikasikan informasi kepada pasien dengan gaya yang dapat dimenegrti dan menghindari terminologi yang hanya dimengerti oleh profesinya sendiri.

Menyampaikan kondisi pasien pada keadaan yang sebenarnya secara teori harus diberikan, karena merupakan hak pasien untuk mendapatkan informasi yang sejelas-jelasnya, sehingga pasien merasa jelas tentang kondisi kesehatan pasien, tetapi secara psikologis perlu diperhatikan dan perlu dipahami oleh tenaga kesehatan adalah 
kesiapan pasien dalam menerima informasi. Perlu dihindari bahwa informasi tentang kesehatan yang diterima justru membebani pikiran pasien atau justru berdampak kurang baik terhadap pasien sendiri.

"kepekaan tenaga rumah sakit terhadap pasien cukup baik. Dimana pegawai diharuskan menanyakan $3 T$ dan $1 D$ setiap hari kepada pasien. Yaitu ;

Tanyakan kondisi pasien

Tanyakan Keluhan pasien

Tanyakan sarana dan prasarana $R S$

Doakan semoga pasien lekas sembuh"

"Interaksi antara pasien dan pegawai $R S$ cukup baik. Apabila terjadi masalah pertama diselesaikan di lingkup ruangan tersebut, apabila tidak teratasi dan berpotensial complain besar maka melibatkan pihak Hukmas."

"para petugas, sudah memberikan yang terbaik bagi pelanggannya atau pasien yang dirawat"

Dengan ditanamkannya sebuah program upaya meningkatkan kepekaan petugas kepada pasien, setidaknya akan mengingatkan betapa pentingnya responsibility petugas kesehatan terhadap kondisi pasien. Petugas kesehatan selalu ingat untuk menanyakan 3T 1D setiap dekat dengan pasien.

Selanjutnya tentang pentingnya kepekaan terhadap masalah pasien, responden memberikan pernyaan seba-gai berikut:

"mungkin menurut saya para petugas kesehatan di RSUP ini ada yang peka tapi juga ada yang kurang peka"

"maksudnya tenaga kesehatan harus bisa merasakan apa yang sedang dirasakan oleh pasien, bukan pasien yang harus merasakan apa yang dirasakan petugas, perawatnya"

Memperhatikan pernyataan responden tersebut menunjukan bahwa kepekaan (responsiveness), merupakan sebuah model yang dikembangkan oleh Zeitham, tahun 1992, digunakan untuk mengukur kualitas layanan dan untuk mengukur tingkat kepuasan pelanggan. tidak semata-mata dengan mudah dilaksanakan oleh setiap orang, tetapi kepekaan perlu diasah, dibiasakan untuk memiliki perhatian kepada lingkungannya, tetapi juga tidak dapat disamakan dengan suka mencampuri urusan orang lain. Tetapi responsiveness, sebagaikeinginan untuk membantu memberikan layanan yang cepat dan mengatasi komplein dengan baik

Responsibility, tanggap atau istilah lain, dalam kehidupan sehari hari akan semakin terasa ketika berada di area / wilayah yang belum pernah didatangi atau area yang masih asing, maka ketika ada suara " selamat pagi pak, ada yang dapat saya bantu", kalimat sederhana ini sudah memberikan rasa nyaman / aman ketika dalam kebingungannya, sehingga tanggapan ini menjadi sarana untuk mencapai kepuasan pelanggan.

Kebijakan atau policy, merupakankeputusan formal organisasi, yang mengikat dan mengatur tingkah laku atau dapat juga dikatakan sebagai aturan yang mengikat tingkah laku yang memaksa pada anggota untuk mengikutinya. Kebijakan dan hukum berbeda, kebijakan bersifat problem solving dan proaktif, sedangkan hukum lebih bersifat adaptif dan intepretatif.

"Jam buka pelayanan sudah sesuai kebutuhan pasien tapi pelayanan parkir memang belum memuaskan. Fasilitas umum yang disediakan sudah cukup membantu tapi belum berimbang di setiap ruang karena mushola dan toilet umum tidak tersebar merata di seluruh area $R S^{\prime \prime}$

"Para pegawai cukup responsive dengan pelanggan. Terbukti jika ada bel berbunyi, petugas segera menghampiri menanyakan kebutuhan pasien. Selain itu terdapat pojok customer Service di beberapa ruangan cukup membantu /merespon kebutuhan pasien"

Kebijakan sebagai peraturan yang harus dilaksanakan menunjuk pada peraturan berkunjung pada pasien, peraturan penunggu pasien dan peraturan lainnya yang diberlakukan di rumah sakit umum pusat Dr. Kariadi Semarang dan harus dipatuhi oleh semua yang menggunakan atau memanfaatkannya.

\section{Model Manajemen Kasus.}

Model segitiga pelayanan, memberikan model interaktif manajemen yang mencerminkan tiga hubungan terdiri dari tiga elemen yaitu strategi layanan, sumber daya manusia, sistem layanan dengan pelanggan sebagai titik pusat. (rangkuti 2006),

Masing masing elemen dalam segitigatersebut memiliki peran dan status yang berbeda dan supaya memiliki anggapan yang sama terhadap manajemen pelayanan maka harus diketahui apa yang perlu untuk atau yang diinginkan pasien pada akhirnya pelanggan, model ini juga dapat diterapkan dari model pelayanan yang dilakan di rumah sakit, dengan pernyaan responden sebagai berikut:

"Tempat pelayanan yang nyaman selalu 
berusaha dipenuhi dengan menjaga kebersihan $R S . "$

"Pelayanan yang cepat, tepat dan ramah diusahakan dengan melakukan asuhan dengan berorientasi pada keselamatan pasien, diciptakannya respon time untuk pelayanan tertentu sebagai indicator mutu unit".

Model ini dapat dipraktikan dalam lingkungan rumah sakit, dalam tujuannya adalah melayani kebutuhan passien dan bukan menghasilkan produk sehingga unsur manusia perlu mendapatkan perhatian yang sangat penting, karena dapat berhubungan dengan masalah perilaku manusia sebagai pelanggan dan etika sebagai konsekeuensi lain yang perlu diperhatikan juga.

Disamping itu model manajemen segitiga ini berbeda fokus yang harus dilaksanakan bila diterapkan dalam lingkungan rumah sakit, sebab fokus pelanggannya tidak dapat satu, misalnya pasien pngguna jasa pelayanan dari sebuah rumah sakit, ternyata bukan karena pilihan pasien tetapi ternyata karena Asuransi Kesehatan yang memilihkan untuk itu. Dapat juga pemeilihan rumah sakit karen pilihan yang dilakukan oleh dokter karena

Namun demikian pernyataan res-ponden sehubungan dengan model segitiga manajemen yang semata mata pada produk jasa, dapat saja terjadi pada model-model manajemen pelayanan yang lainnya.

\section{Kolaborasi Antar Profesi (Inter-profesional Colaboration)}

Pengelolaan kasus di rumah sakit dan sistem pelayanan kesehatan adalah model praktek kolaboratif yang mencakup pasien, perawat, pekerja sosial, dokter, tenaga kesehatan lain, pemberi pelayanan, dan komunitas. Pengelolaan kasus ini mencakup komunikasi dan memfasilitasi pelayanan menjadi satu kontinuum melalui koordinasi sumber daya yang efektif. Dan dalam implementasinya dalam manajemn kasus ini secara teori dilaksanakan minimal oleh dua profesi yang berperan selaku penanggung jawab maupun satu profesi lainnya sebagai pelaksananya.

Secara konsep pengeloalaan kasus bisa berasal dari kalangan perawat senior, atau dokter, atau profesi lain. Dengan pola pendidikan dan budaya sistem kesehatan Indonesia, rasanya agak mustahil bila pengelola kasus ini non perawat atau non dokter.

Dalam implementasi model Case
Manajemen dengan berbagai hambatannya telah dilaksanakan, dengan DPJP (Dokter Penanggung Jawab Pasien) berasal dari profesi dokter, hal ini sesuai pernyataan responden

"Sudah dilakukan, bisa dili-hat dalam lembar interdispilin dan lembar catatan terintegrasi dimana semua layanan yang diberikan kepada pasien ditulis dalam satu rekam medis agar layanan yang diberikan bisa berkesinambungan."

Memperhatikan pernyataan terse-but, bahwa bukti pelaksanaan manajemen kasus, telah disiapkan form tersendiri sebagai catatan terintegrasi yang menampung semua dokumen kegiatan dari berbagai profesi yang terlibat dalam manajemen kasus yang sekaligus sebagai sarana komunikasi antar profesi yang masih terdapat hambatan dalam melaksanakan pembahasan masalah pasien secara bersama-sama (duduk bersama), sebagaimana pernyataan responden :

"Hambatan yang sering terjadi adalah waktu untuk duduk bersama untuk mendiskusikan pa-sien yang dikelola antar pemberi pelayanan, belum bisa berjalan dengan baik. Kendala utama adalah waktu dari DPJP (Dokter Penanggung Jawab Pasien)."

"semua pasien yang dirawat akan dilayani oleh profesinya masing masing, dokter, perawat atau bidan, apoteker, bagian gizi dan lainya"

\section{Koordinasi Sumber Daya.}

Satu hal lagi dalam Case Manajemen adalah adanya koordinasi antar profesi, artinya selama pasien dirawat dan dilaksanakannya model Case Manajemen dalam implementasi asuhannya, maka diperlukan koordinasi dalam pelayanannya. Hal ini dilakukan agar pasien mendapatkan pelayanan yang komprehensive menjadi satu kontinum melalui kordinasi yang efektif, sesuai pernyataan responden sebagai berikut:

"Selama proses rawat inap pasien akan mendapatkan pelayanan secara komprehensif sesuai dengan kebutuhan pasien."

"Pelaksanaannya adalah sitem perawatan kolaborasi antar Professional Pemberian Asuhan (PPA). Bukti kolaborasi tersebut tertuang dalam rekam medis di catatan terintegrasi."

Kemudian sebutan untuk pelaksana disebut dengan Profesional Pemberi Asuhan (PPA), dan dalam kondisi tertentu terdapat pula sosial worker yang dapat memberikan asuhan/pelayanan dibidang sosialnya, misalnya pasien tanpa keluarga. 
Komunikasi dan koordinasi antar profesi.

Komunikasi dan interaksi Profesional dan pasien menjadi sangat penting, untuk memberikan kepuasan. Komunikasi dalam asuhan di atas pelayanan yang diberikan RSUP Dr. Kariadi dilakukan mini-mal dengan selalu mengingat dan melaksanakan apa yang disebut 3T 1D disetiap hari kepada Pasien.

Dengan komunikasi dan koordinasi juga digunakan untuk menyelesaikan masalah atau konflik atau komplain yang mungkin muncul dengan penyelesaian secara internal dalam tim koalborasi.

Prosedur pelayanan pasien diawali dengan pasien masuk di Poliklinik rawat jalan atau melalui UGD kemudian dilakukan penapisan, kemudian dilanjutkan dengan pengkajian atau asesman awal oleh tenaga medis atau perawat, untuk mendapatkan atau ditemukannya masalah pasien (diagnose) baru pasien dinyatakan harus mondok atau sebaliknya.

Selanjutnya apabila dilaksanakan perawatan di rumah sakit, maka pelaksanaannya dengan sistem perawatan kolaboratif antar Profesional Pemberi Asuhan.

\section{Pengelolaan Sumber daya dan Advokasi.}

Setelah pasien dinyatakan perlu pelayanan lebih lanjut dengan dinyatakan perlu mondok atau dirawat maka prosedur administrasi rawat inap segera dilaksanakan.

Hal penting yang berkaitan dengan Manajemen kasus adalah penilaian kasus pasien, diperlukan atau tidaknya model pelayanan Manajemen Kasus, dibuat oleh perawat atau dokter sesuai kebutuhan. Seperti diungkapkan oleh responden terhadap pelaksanaan Manajemen Kasus:

"Apabila diperlukan kolaborasi antar berbagai Profesional Pemberi Asuhan juga akan dilakukan hal tersebut."

Dengan pernyataan tersebut menunjukan bahwa pengelolaan pasien yang menggunakan model Manajemen Kasus belum semua diberikan pelayanan dengan model tersebut. Masih membutuhkan pertimbangan pertimbangan untuk dapat dilaksanakannya. Data tentang hak tersebut masih perlu digali lagi melalui sumber informasi yang sahih.

\section{Simpulan}

Hasil penelitian tentang aspek persepsi Kualitas, Manajemen dan SDM Kesehatan di RS Dr. Kariadi Semarang yaitu asuhan kesehatan pada pasien dari aspek persepsi.Pelayanan Kesehatan dari Persepsi Kualitas yang dilaksanakan di RSUP Dr. Kariadi Semarang, meng-gunakan standar ukuran kualitas tindakan dengan SPO, menggunakan prinsip nilai yang diyakini baik, yaitu nilai lokal seperti kepercayaan, integritas dan peduli. Juga standart ukuran lain yang digunakan yaitu menggunakan indikator IPSG (International Patient Safety Goal) ada 6 sasaran keselamatan pasien. IPSG ini dikeluarkan oleh JCI (Joint Commission International) sebuah lembaga yang memberi perhatian terhadap kualitas dan keselamatan kesehatan. Program lain dalam upaya meningkatkan kepekaan atau responsibility tenaga kesehatan baik dokter, perawat, bidan maupun tenaga kesehatan lainnya yang dekat dengan pasien, setidaknya akan mengingatkan betapa pentingnya responsibility petugas kesehatan terhadap kondisi pasien. Petugas kesehatan selalu diingatkan untuk menanyakan 3T 1D setiap dekat dengan pasien.

Manajemen Pelayanan Asuhan, dalam Case Manajemen salah satu tindakanyang penting adalah adanya koordinasi antar profesi, artinya selama pasien dirawat dan dilaksanakannya model Case Manajemen dalam implementasi asuhannya, maka diperlukan koordinasi dalam pelayanannya. Hal ini dilakukan agar pasien mendapatkan pelayanan yang komprehensive menjadi satu kontinum melalui kordinasi yang efektif.

Dalam implementasinya model Case Manajemen dengan berbagai hambatannya dan keku-rangannya dengan DPJP (Dokter Penanggung Jawab Pasien) berasal dari profesi dokter dan PPA (Profesional Pemberi Asuhan) yang berasal dari tenaga profesi lainnya, model manajemen kasus ini telah dilaksanakan di RSUP Dr. Kariadi Semarang.

Memperhatikan pernyataan tersebut, bahwa bukti pelaksanaan manajemen kasus, atau yang disebut dengan Interprofesiomnal Colaboration (IPC), belum sepenuhya dilaksanakan, artinya untuk memenuhi kekurangan dalam implementasi IPC telah disiapkan form tersendiri sebagai catatan terintegrasi yang menam-pung semua dokumen kegiatan dari berbagai profesi yang terlibat dalam manajemen kasus yang sekaligus sebagai sarana komu-nikasi antar profesi yang masih terdapat hambatan dalam melaksanakan pembahasan masalah pasien secara bersama-sama. 
Manajemen SDM, arah Pengembangan karir di RSUP Dr. Kariadi Semarang, dinilai cukup bagus dan memiliki jenjang karir yang sudah tertata dan terukur, ada pendidikan berkelanjutan, ada kegiatan in service training, ada analisis kebutuhan pegawai dan sebagainya.

Penempatan tenaga telah dilaksanakan melalui analisis yang matang dan sesuai dengan ke-butuhan akan tenaga pelayanan yang sesuai. Bagian SDM besertadenganbagianlain yang terkait (bidan pelayanan medik, bidang pelayanan keperawatan) melakukan mapping tenaga kemudian menempatkan pegawai sesuai dengan kompetensi dan kebutuhan ruangan".

Saran yang dapat peneliti sampaikan sehubungan dengan persepsi yang nota benenya penilaiannya sangat individual dan mudah berubah-rubah, maka untuk hal tersebut program menjaga persepsi kualitas tersebut untuk tidak mengendorkan semangat untuk terus meningkatkan kualitas pelayanan. Dalam implementasinya model Case Manajemen dengan berbagai hambatannya dan kekurangannya dengan DPJP (Dokter Penanggung Jawab Pasien) berasal dari profesi dokter dan PPA (Profesional Pemberi Asuhan) yang berasal dari tenaga profesi lainnya, model manajemen kasus atau dise-but juga interprofesional colaboration ini telah dilaksanakan di RSUP Dr. Kariadi Semarang, namun masih banyak yang harus ditingkatkan, utamanya kesediaan tim untuk duduk bersama membahas masalah pasien.Hal tersebut sangat penting dilakukan, mengingat dengan duduk bersama, diskusi bersama banyak hal yang dapat diperoleh untuk kepentingan pasien dan tenaga kesehatan sebagai pelaksananya, antara lain interaksi dan komunikasi antar profesi semakin baik, semua persoalan pasien dapat segera diatasi.Sebagai saran untuk pengeloaan sumber daya manusia, kiranya cukup untuk menyampaikan umtuk dipertahankan dan ditingkatkan segala upaya dan program yang telah dilakukan.

\section{Daftar Pustaka}

Alfi Febriana Rahmawati, Stefanus Supriyanto, (2013) Mutu Pela-yanan Kesehatan Berdasarkan Demensi Dabholkar di Ruang Rawat Inap Penyakit Dalam, Jurnal Administrasi Kesehatan Indonesia Volume 1 Nomor 2 April-Juni 2013

Anada Kaporina (1), Muh. Hidayat Setyawan (2), Andra Novitasari (3), 2013 Gambaran Tingkat Kepuasan Pasien Terhadap Pelayanan di Instalasi Rawat Inap Ruang B2 THT \& Kulit Kelamin RSUP Dr. Kariadi Semarang, Prosiding Konferensi Nasional PPNI Jawa Tengah 2013.

Antin Yohana, 2009, Analisis Harapan dan Kepuasan Pasien Rawat Inap Penyakit Dalam Terhadap Mutu Pelayanan Dokter Spesialis di RSI Sunan Kudus, Progdi Magister Kesehatan Masyarakat, UNDIP Semarang.

Departemen Kesehatan RI. 1995. Konsep Kebidanan. Jakarta: Departemen Kesehatan RI

Estiwati, D; Meilani , N; Widyasi, H; Widyastuti, Y. 2009. Konsep Kebidanan. Jogjakarta:

Tjiptono, F., 2011, Service, Quality, \& Satisfaction. Yogyakarta: ANDI. i Offset

Tjiptono,F. 2014, Jasa-Prinsip, Pene-rapan, dan Penelitian, Yogya-karta: And

Improtul Khasanah, 2010, Analisis Pengaruh Kualitas Pelayanan terhadap Kepuasan Konsumen RS St. Elisabeth Semarang Jurusan Manajemen Fakultas Ekonomi Universitas Dipo-negoro, Aset, Februari 2010, hal. 117-124 Vol. 12 No. 2 ISSN 1693-928X

Ketut Gunawan dan Sundring Pantja Djati, 2011, Kualitas Layanan dan Loyalitas Pasien ( Studi pada Rumah Sakit Umum Swasta di Kota Singaraja - Bali, Jurnal Manajemen dan Kewirausahaan, Vol: 13, No: 1 tahun 2011.

Profil Rumah Sakit Dr. Kariadi Semarang, 2016.

Sofyan, Mustika. 2004. Bidan Menyong-song Masa Depan; 50 Tahun Ikatan Bidan Indonesia. Jakarta: PP IBI.

Robertus Arian Datusanantyo, 2014. Case Manager Profesi Baru di Rumah Sakit Indonesia), yang termuat dalam (https://www. Mutupelayanan kesehatan.net/19-headline/1373-case- 
manager-profesi-baru-di-rumah-sakit-

indonesia), tanggal: 20 May 2014.

Varadina Ayu N, 2016. Model Pelayanan

Kesehatan (Studi Des-kriptif Tentang Model

Pelayanan Program Antenatal care di

Puskesmas Peterongan Kabupa-ten

Jombang), Jurnal Kebijakan dan Manajemen Publik ISSN 2303 - 341X, Volume 4, Nomor 3, September - Desember 2016

Wike Diah Anjaryani, 2009, Kepuasan Pasien Rawat Inap Terhadap Pelayanan Perawat di RSUD Tugurejo Semarang, Magister Promosi Kesehatan, Kajian Sumber Daya Manusia Program Pascasarjana Universitas Dipo-negoro Semarang, 2009. 